\title{
The change in NT-pro-BNP and post-PTMC echocardiography parameters in patients with mitral stenosis. A pilot study
}

\author{
MORTEZA SAFI ${ }^{1}$, FARIBA BAYAT ${ }^{2}$, ZAHRA AHMADI $^{3}$, MASOOD SHEKARCHIZADEH ${ }^{4}$, \\ ISA KHAHESHI ${ }^{5}$, MOHAMMADREZA NADERIAN ${ }^{6}$ \\ ${ }^{1}$ Cardiovascular Research Center, Modarres Hospital, ShahidBeheshti University of Medical Sciences, Tehran, Iran \\ ${ }^{2 *}$ Cardiovascular Research Center, Modarres Hospital, ShahidBeheshti University of Medical Sciences, Tehran, Iran \\ ${ }^{3}$ Cardiovascular Research Center, Modarres Hospital, ShahidBeheshti University of Medical Sciences, Tehran, Iran \\ ${ }^{4}$ Cardiovascular Research Center, Modarres Hospital, ShahidBeheshti University of Medical Sciences, Tehran, Iran \\ ${ }^{5}$ Cardiovascular Research Center, Modarres Hospital, ShahidBeheshti University of Medical Sciences, Tehran, Iran \\ ${ }^{6}$ Non-Communicable Diseases Research Center, Endocrinology and Metabolism Population Sciences Institute, \\ Tehran University of Medical Sciences, Tehran, Iran. Students Scientific Research Center (SSRC), \\ Tehran University of Medical Sciences, Tehran, Iran
}

Background. The change in the level of NT-pro-BNP (N-terminal-pro-Brain Natriuretic Peptide) is now considered as a reflection of the hemodynamic alterations and its circulatory reductions reported early after successful PTMC (percutaneous transvenous mitral commissurotomy). The present study aims to assess the change in the level of NT-pro BNP following PTMC in patients with mitral stenosis and also to determine the association between circulatory NT-pro-BNP reduction and post-PTMC echocardiography parameters.

Methods. Twenty five symptomatic consecutive patients with severe MS undergoing elective PTMC were prospectively enrolled. All patients underwent echocardiography before and also 24 to 48 hours after PTMC. Peripheral blood samples were taken for measurement of NT-pro-BNP before as well as 24 to 48 hours after PTMC. The patients were also classified in group with normal sinus rhythm or having atrial fibrillation (AF) based on their 12-lead electrocardiogram.

Results. It was shown a significant decrease in the parameters of PPG (Peak Pressure Gradient), MPG (Mean Pressure Gradient), PHT (Pressure Half Time), PAP (Pulmonary Arterial Pressure), LAV (Left Atrial Volume), and also a significant increase in MVA (Mitral Valve Area) RVS (Right Ventricular S velocity), and strains of lateral, septal, inferior and anterior walls of LA following PTMC. The mean LVEF remained unchanged after PTMC. The mean NT-pro-BNP before $\mathrm{PTMC}$ was $309.20 \pm 17.97 \mathrm{pg} / \mathrm{lit}$ that significantly diminished after PTMC to $235.72 \pm 22.46 \mathrm{pg} / \mathrm{lit}$ $(\mathrm{p}=0.009)$. Among all echocardiography parameters, only MPG was positively associated with the change in NT-pro-BNP after PTMC. Comparing the change in echocardiography indices between the patients with normal rhythm and those with AF, lower change in PAP was shown in the group with AF. However, more change in the level of NT-pro-BNP after PTMC was shown in the patients with AF compared to those without this arrhythmia.

Conclusion. PTMC procedure leads to reduce the level of NT-pro-BNP. The change in NT-pro-BNP is an indicator for change in MS severity indicated by decreasing MPG parameter. Lower change in PAP as well as higher change in NT-pro-BNP is predicted following PTMC in the group with AF compared to those with normal sinus rhythm.

Keywords: pro-brain natriuretic peptide, Mitral Valve Stenosis, Echocardiography.

\section{INTRODUCTION}

N-terminal pro b-type natriuretic peptide (NT-pro-BNP) is essentially applied to evaluate and diagnose the severity of heart failure [1]. In fact, cardiac ventricular myocytes constitute the main source of this activated peptide and thus its rise is evident when the heart is abnormally stretched in cases with heart failure, valvular heart diseases and even cardiac ischemic events [2,3]. Moreover, the increase in this biomarker can predict the risk for recurrent cardiac events and poor outcome of cardiac surgical procedures [4]. Recent studies have identified this marker as a precious indicator of the severity of valvular heart disease, in addition to other basic assessments including clinical and echocardiographic evaluations $[5,6]$. On the other hand, the level of NT-pro BNP levels has been revealed to correlate directly with the severity of mitral stenosis and thus considerable reduction of this marker is predictable after successful correction of the stenotic valve [7]. Physiologically, since percutaneous transvenous mitral commissurotomy (PTMC) as a choice treatment approach in patients 
with mitral stenosis leads to rapid decreases in left atrial pressures and subsequent decreases in pulmonary artery pressure (PAP), it is possible that the change in the level of NT-pro-BNP may be considered as a reflection of the hemodynamic alterations [8]. Thus, reduction in circulatory level of NT-pro-BNP levels can be reported early after successful PTMC $[9,10]$. The present study intends to assess the change in the level of NT-pro-BNP following PTMC in patients with mitral stenosis and the association between circulatory NT-pro-BNP reduction and post-PTMC echocardiography parameters. Also, the association between lowering PAP after PTMC and the level of NT-pro BNP was assessed.

\section{MATERIALS AND METHODS}

In total, 25 symptomatic consecutive patients with severe MS (based on the measurement of mitral valve area) undergoing elective PTMC in Modarres Hospital in 2014-2015 were enrolled prospectively. The cutoff value used to recommend the procedure was mitral valve area in planimetry $<$ $1.5 \mathrm{~cm}^{2}$. A written informed consent was obtained from all subjects before participation in the study. Exclusion criteria were left ventricular ejection fraction (LVEF) less than $50 \%$, history of systemic hypertension, history of myocardial infarction or known coronary artery disease, renal failure of stage 3 or higher, severe chronic obstructive pulmonary disease, incomplete echocardiography data, thrombus in left atrium or left appendage and pulmonary edema. Demographic and anthropomorphic data including age, gender, height and weight, and body mass index (BMI) were collected and recorded. The patients were also classified in group with normal sinus rhythm or having atrial fibrillation (AF) based on their 12-lead electrocardiogram. Clinical information such as heart rhythm, and history of comorbid diseases were also gathered. All patients underwent echocardiography before and also 24 to 48 hours after PTMC to measure echocardiography parameters including mitral valve area (MVA), peak pressure gradient (PPG), mean pressure gradient (MPG), pressure half-time (PHT), right ventricular end diastolic diameter (RVEDD), right ventricular annular $S$ velocity (RVS), tricuspid annular plane systolic excursion (TAPSE), pulmonary artery pressure (PAP), left atrial volume in the apical 4-chamber view (4C) and apical 2-chamber view (LAV2c and LAV4c), and also strains of lateral, septal, inferior and anterior walls of LA by tissue Doppler imaging. Peripheral blood samples for measurement of
NT-pro BNP were taken from all patients before as well as 24 to 48 hours after PTMC procedure. NT-pro-BNP of greater than $125 \mathrm{pg} / \mathrm{mL}$ was defined indicator of cardiac dysfunction. PTMC was executed via a femoral approach with the patient under conscious sedation. Successful PTMC was defined as MVA $\geq 1.5 \mathrm{~cm}^{2}$ or $\geq 1 \mathrm{~cm}^{2} / \mathrm{m}^{2}$ without significant complications including new mitral regurgitation or acceleration of previous mild mitral regurgitation.

For statistical analysis, quantitative variables were presented as mean \pm standard deviation and categorical variables were presented by absolute frequencies and percentages. The change in study parameters after PTMC was assessed using the paired $\mathrm{t}$ test or Wilcoxon test. The correlation between quantitative parameters was tested using the Pearson's or Spearman's correlation coefficient tests. P values of $\leq 0.05$ were considered statistically significant. Data were analyzed using IBM SPSS statistical software version 21.0 (Armonk, NY: IBM Corp.).

\section{RESULTS}

The mean age of participants was $44.36 \pm$ 11.36 years ranged 24 to 65 years and $84 \%$ were male. Regarding cardiac rhythm status, $60 \%$ had normal sinus rhythm, while $40 \%$ had AF. The considered etiology of mitral stenosis was rheumatic involvement due to history and echocardiographic findings. 18 patients were new cases of mitral stenosis who did not receive any medical treatment before diagnosis of mitral stenosis; 7 patients were known cases of mitral stenosis who were under treatment of warfarin and low dose diuretic. 17 patients had score of 8 and 8 patients had score of 7 , according to Wilkins score in echocardiography. Table 1 summarizes echocardiography parameters before and after PTMC in affected patients. According to these results, it was shown a considerable decrease in the parameters of PPG, MPG, PHT, PAP, LAV, and a significant increase in other parameters including MVA, RVS velocity, and LA strain of lateral, septal, inferior and anterior walls following PTMC. The mean LVEF remained unchanged after PTMC. The mean NT-pro-BNP before PTMC was $309.20 \pm 17.97 \mathrm{pg} / \mathrm{lit}$ that notably reduced after PTMC to $235.72 \pm 22.46(\mathrm{p}=$ 0.009). As shown in Table 2 and Figure 1, among all echocardiography parameters, only MPG was positively associated with the change in NT-proBNP after PTMC. Comparing the change in echocardiography indices between the patients with normal rhythm and those with AF (Table 3) lower 
change in PAP was shown in the group with AF in comparison with the group with normal sinus rhythm $(8.00 \pm 6.94$ versus $22.47 \pm 13.31, \mathrm{p}<$ 0.001). However, more change in the level of NTpro-BNP after PTMC was shown in the patients with $\mathrm{AF}$ compared to those without this arrhythmia $(3.80 \pm 0.15$ versus $1.25 \pm 0.07, p<0.001)$. There was no new significant mitral regurgitation or acceleration of mild mitral regurgitation after percutaneous transvenous mitral commissurotomy.

Table 1

Echocardiography parameters before and after PTMC

\begin{tabular}{|c|c|c|c|}
\hline $\operatorname{MVA}\left(\mathrm{cm}^{2}\right)$ & $0.97 \pm 0.24$ & $1.76 \pm 0.21$ & $<0.001$ \\
\hline PPG(mmHg) & $23.21 \pm 8.39$ & $12.98 \pm 4.11$ & $<0.001$ \\
\hline MPG(mmHg) & $11.94 \pm 5.41$ & $5.92 \pm 3.00$ & $<0.001$ \\
\hline PHT(msec) & $211.48 \pm 47.94$ & $127.20 \pm 29.61$ & $<0.001$ \\
\hline RVEDD(mm) & $30.76 \pm 2.99$ & $30.64 \pm 2.99$ & 0.327 \\
\hline RVS velocity $(\mathrm{cm} / \mathrm{sec})$ & $11.56 \pm 2.04$ & $12.16 \pm 1.95$ & 0.001 \\
\hline TAPSE(mm) & $21.20 \pm 3.73$ & $21.28 \pm 3.66$ & 0.425 \\
\hline PAP(mmHg) & $55.52 \pm 15.48$ & $38.84 \pm 8.64$ & $<0.001$ \\
\hline LAV (2ch)(cc) & $68.28 \pm 12.48$ & $66.72 \pm 12.81$ & $<0.001$ \\
\hline LAV (4ch)(cc) & $89.16 \pm 23.16$ & $83.32 \pm 17.56$ & 0.004 \\
\hline Strain (lateral)\% & $20.96 \pm 30.53$ & $22.52 \pm 6.95$ & $<0.001$ \\
\hline Strain (septal)\% & $22.36 \pm 7.47$ & $23.40 \pm 7.63$ & $<0.001$ \\
\hline Strain (inferior)\% & $21.92 \pm 2.66$ & $23.36 \pm 10.05$ & $<0.001$ \\
\hline Strain (anterior)\% & $21.72 \pm 9.24$ & $22.72 \pm 8.84$ & 0.030 \\
\hline
\end{tabular}

Abbreviations: MVA: Mitral valve area; PPG: Peak pressure gradient; MPG: Mean pressure gradient; PHT: Pressure half-time; RVEDD: Right ventricular end diastolic diameter; RVS: Right ventricular S; TAPSE: Tricuspid annular plane systolic excursion; PAP: Pulmonary arterial pressure; LAV: Left atrial volume.

Table 2

Association between the change in NT-pro-BNP and the change in echocardiography parameters after PTMC

\begin{tabular}{lll} 
MVA & -0.308 & 0.134 \\
\hline PPG & 0.128 & 0.541 \\
\hline MPG & 0.462 & 0.020 \\
\hline PHT & 0.157 & 0.455 \\
\hline RVEDD & 0.206 & 0.323 \\
\hline RVS velocity & -0.124 & 0.524 \\
\hline TAPSE & 0.322 & 0.117 \\
\hline PAP & 0.342 & 0.094 \\
\hline LAV (2ch) & 0.248 & 0.233 \\
\hline LAV (4ch) & 0.232 & 0.264 \\
\hline Strain (lateral)\% & -0.257 & 0.215 \\
\hline Strain (septal)\% & -0.039 & 0.854 \\
Strain (inferior)\% & -0.061 & 0.771 \\
\hline Strain (anterior)\% & 0.048 & 0.819
\end{tabular}

Abbreviations: MVA: Mitral valve area; PPG: Peak pressure gradient; MPG: Mean pressure gradient; PHT: Pressure half-time; RVEDD: Right ventricular end diastolic diameter; RVS: Right ventricular S; TAPSE: Tricuspid annular plane systolic excursion; PAP: Pulmonary arterial pressure; LAV: Left atrial volume. 
Table 3

Change in study parameters following PTMC in the groups with and without AF

\begin{tabular}{|lrrr}
\hline NT-Pro-BNP(pg/lit) & $3.80 \pm 0.15$ & $1.25 \pm 0.07$ & $<0.001$ \\
\hline MVA(cm $\left.{ }^{2}\right)$ & $0.77 \pm 0.22$ & $0.81 \pm 0.21$ & 0.681 \\
\hline PPG(mmHg) & $9.06 \pm 4.81$ & $11.01 \pm 6.73$ & 0.438 \\
\hline MPG(mmHg) & $4.36 \pm 2.53$ & $7.13 \pm 4.28$ & 0.079 \\
\hline PHT(msec) & $66.80 \pm 34.51$ & $95.93 \pm 47.04$ & 0.107 \\
\hline RVEDD(mm) & $0.15 \pm 0.10$ & $0.20 \pm 0.77$ & 0.426 \\
\hline RVS velocity(cm/sec) & $0.60 \pm 0.70$ & $0.60 \pm 0.83$ & 0.999 \\
\hline TAPSE(mm) & $0.20 \pm 0.42$ & $0.01 \pm 0.53$ & 0.331 \\
\hline PAP(mmHg) & $8.00 \pm 6.94$ & $22.47 \pm 13.31$ & 0.005 \\
\hline LAV (2ch) & $2.30 \pm 2.79$ & $2.73 \pm 2.34$ & 0.679 \\
\hline LAV (4ch) & $3.10 \pm 3.07$ & $7.67 \pm 11.34$ & 0.229 \\
\hline Strain (lateral)\% & $1.00 \pm 0.47$ & $1.93 \pm 2.19$ & 0.200 \\
\hline Strain (septal)\% & $0.80 \pm 0.63$ & $1.20 \pm 1.37$ & 0.400 \\
\hline Strain (inferior)\% & $0.90 \pm 0.99$ & $1.80 \pm 2.11$ & 0.223 \\
\hline Strain (anterior)\% & $1.30 \pm 1.06$ & $0.80 \pm 2.68$ & 0.582 \\
\hline
\end{tabular}

Abbreviations: MVA: Mitral valve area; PPG: Peak pressure gradient; MPG: Mean pressure gradient; PHT: Pressure half-time; RVEDD: Right ventricular end diastolic diameter; RVS: Right ventricular S; TAPSE: Tricuspid annular plane systolic excursion; PAP: Pulmonary arterial pressure; LAV: Left atrial volume.

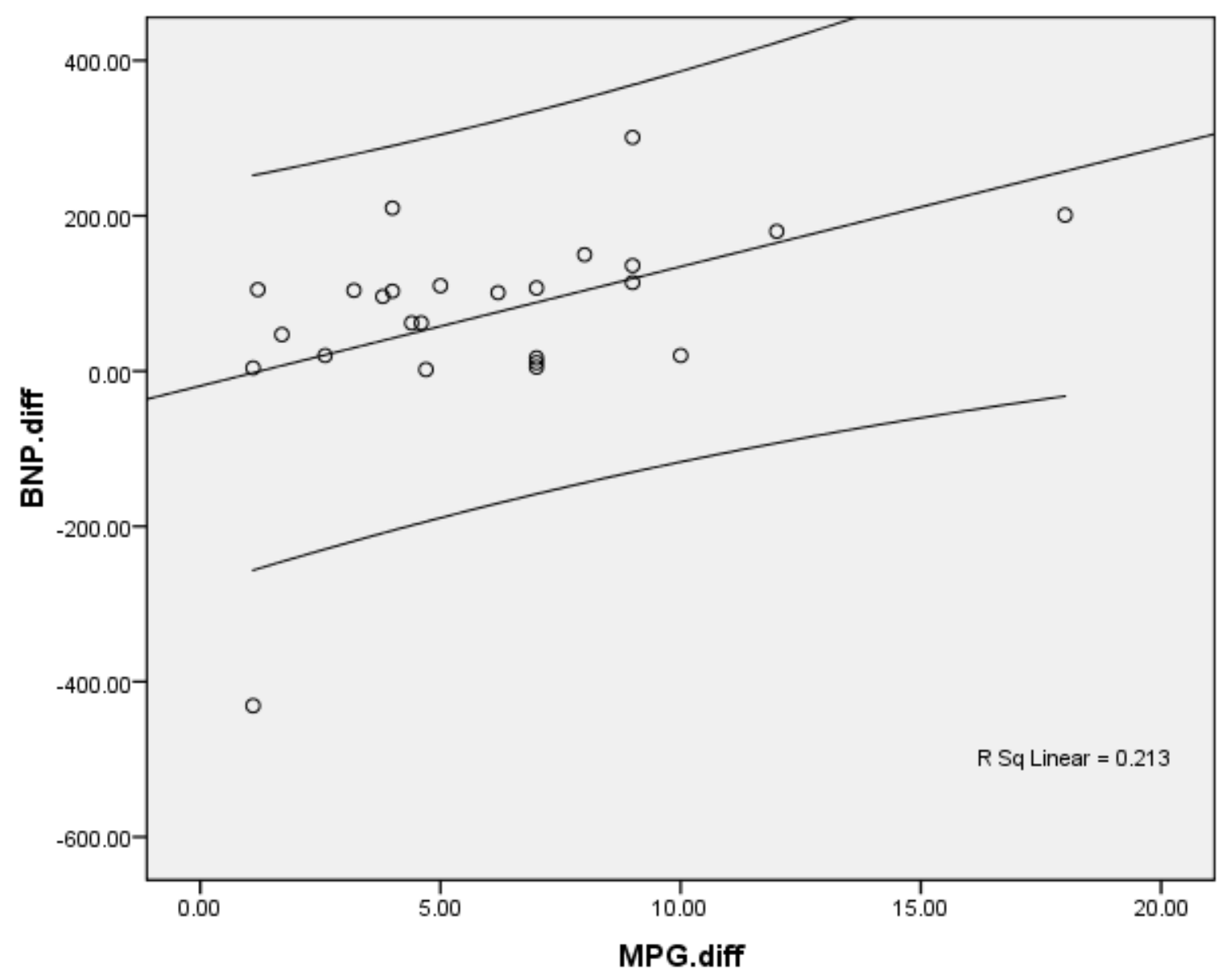

Figure 1. Association between BNP level and MPG. 


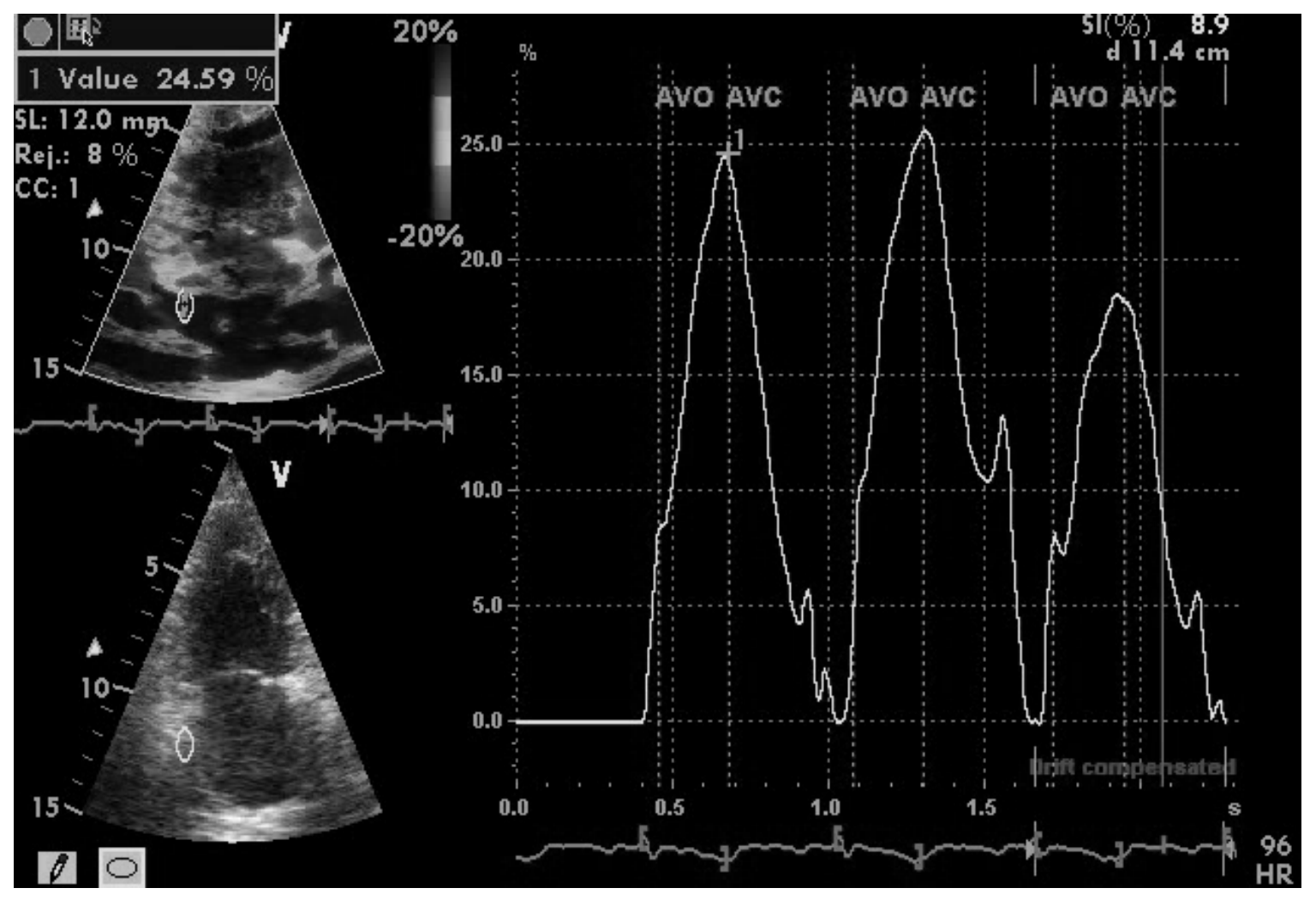

Figure 2. LA strain measurement based on tissue Doppler imaging.

\section{DISCUSSION}

According to previous findings on hormonal components secreted from atrial and ventricular cells in response to strain changes and wall motion abnormalities, the current study aimed to assess the relationship between the changes in NT-pro-BNP and echocardiography parameters. In this regard, the first imperative finding was that among all parameters, MPG was associated with the change in NT-pro-BNP. MPG is an indicator for valvular pressure gradient, particularly for mitral valve. In fact, the measurement of NT-pro-BNP can be used for assessing mitral stenosis severity as well. Similar to our study, Arat-Ozkan et al. [11] could show that patients with mitral stenosis had higher NT-pro-BNP levels compared to controls, but they also found a significant correlation between NT-pro-BNP and left atrial and right ventricular size as well as mitral valve area, mean mitral gradient, peak PAP and NYHA functional class. Interestingly, similar to our observation, they showed that those with atrial fibrillation had significantly higher NT-pro-BNP levels compared to those with sinus rhythm. In the same way, Eryol et al. [12] indicated that NT-proBNP level in the group with severe mitral stenosis was considerably higher than that in the mild mitral stenosis and, in fact, when patients were taken together, as the area of the mitral valve decreased, the level of BNP underwent a corresponding increase. As shown by Iltumur et al. [13], NT-proBNP levels demonstrated a significantly greater increase in severe MS than in moderate MS; in their study, there was a positive correlation with pulmonary artery pressure and a negative correlation with mitral valve area. Some studies could also demonstrate high value of increasing level of NTpro-BNP in differentiating severe mitral stenosis from mild type. So Uçar et al. [14] suggested that NT-pro-BNP value of $32 \mathrm{pg} / \mathrm{mlit}$ is the best cut-off value for the determination of patients with mitral stenosis with a positive predictive value of $100 \%$ and a negative predictive value of $75 \%$.

Moreover, a cutoff value of total average LA strain (23.28\%) can discriminate normal and abnormal LA function with a sensitivity of $93 \%$ and specificity of $100 \%$ and LA strain seems to be a better factor for diagnosis of abnormal LA function [15].

According to the present results, increase of the strain of LA walls to more than $23 \%$ is predictive for successful PTMC; however, the relation between NT-pro-BNP and LA strain and other echocardiography indices such as left atrial functional parameters and PAP remains questioned; thus it should be in detail assessed in further studies with a more number of patients. 
As another essential finding, we showed that the presence of atrial fibrillation may confound the relation between NT-pro-BNP and echocardiography indices because of more change in the level of NT-pro-BNP after PTMC in the patients with AF compared to those with normal sinus rhythm. The association between NT-pro-BNP level and atrial fibrillation has been less studied and understood. Some studies have proved that NT-pro-BNP is increased in atrial fibrillation [16-19]. The proposed mechanisms are high frequency of atrial myocyte contraction and local atrial inflammation [18]. It has been also recommended that BNP increases within 4 hours from the onset of atrial inflammation; whether this applies to NT-pro-BNP is also not clear [20]. In demonstrating association between NT-pro-BNP and atrial fibrillation, it has been shown that NT-pro-BNP levels may drop after successful cardioversion of atrial inflammation [17]. Actually, the treatment of atrial inflammation can be reflected by reducing the level of NT-pro-BNP.
As the last point, lower change in PAP as well as higher change in NT-pro-BNP is predicted following PTMC in the group with AF compared to those with normal sinus rhythm in our study; this finding is relatively different from the findings of some other studies [21, 22]. Future studies with large sample size and powerful meta-analysis will reveal more detailed and clear results.

\section{CONCLUSION}

In conclusion, in parallel with previous studies, most atrial and ventricular function parameters in echocardiography improved significantly following PTMC and thus it seems that PTMC is an effective approach to improve cardiac functional indices. In this regard, it seems that improvement of some echocardiography indices such as MPG following PTMC can be predicted by measuring the level of NT-pro-BNP that can be used as an index of successful PTMC in a patient that we could not evaluate PTMC results such a poor echo window.

Introducere. Modificările nivelului NT-pro-BNP sunt considerate secundare modificărilor hemodinamice iar scăderea nivelului acestuia este reflectat după intervenție PTMC (comisurotomie percutană transvenoasă). Studiul îşi propune să evalueze modificările NT-pro- BNP după PTMC la pacienții cu stenoză mitrală şi să evalueze asocierea dintre nivelurile circulatorii ale NT-pro-BNP şi modificarea parametrilor ecocardiografici.

Materiale şi metode. Au fost recrutați 25 de pacienți cu stenoză mitrală severă ce au suferit ulterior PTMC. Toți pacienții au fost evaluați ecocardiografic inainte şi la 24 şi 48 ore după PTMC. Au fost prelevate probe serologice pentru analiza NT-pro-BNP, înainte şi la 24 şi 48 ore post PTMC. Pacienții au fost clasificați în 2 grupe după analiza EKG: fie ritm sinusal sau fibrilație atrială.

Rezultate. După PTMC s-a observant o scădere semnificativă pentru PPG (Peak Pressure Gradient), MPG (Mean Pressure Gradient), PHT (Pressure Half Time), PAP (tensiunea pulmonară arterială), LAV (volumul atriului stâng) şi o scădere a ariei valvei mitrale. Media fracției de ejecție a VS nu s-a modificat după PTMC. Valorile NT-pro-BNP inainte de PTMC au fost de 309,20 $\pm 17,97 \mathrm{pg} / \mathrm{L}$ şi au scăzut semnificativ la 235,72 $\pm 22,46 \mathrm{pg} / \mathrm{L}$ după PTMC $(p=0,009)$.

Dintre toți parametrii ecocardiografici numai $M P G s-a$ asociat pozitiv cu modificările NT-pro-BNP-ului. Comparând modificările parametrilor ecocardiografici între cei cu ritm sinusal şi cei cu fibrilație atrială (AF), la cei cu AF au fost găsite modificări mai mici ale PAP. Valorile NT-pro-BNP-ului au suferit modificări mai mari în subgrupul de pacienți cu AF.

Concluzii. PTMC duce la scăderea NT-pro-BNP-ului. Modificările NT-pro$B N P-u l u i$ sunt un indicator pentru severitatea stenozei mitrale indicate prin scăderea parametrului $M P G$.

Correspondence to: Fariba Bayat, MD, Cardiovascular Research Center, Modarres Hospital,

Shahid Beheshti University of Medical Sciences, Tehran, Iran

E-mail: tehranheartgroup@gmail.com, faribaa.bayat@gmail.com 


\section{REFERENCES}

1. SITAR TAUT AV., POP D., ZDRENGHEA DT. NT-probnp values in elderly heart failure patients with atrial fibrillation and diabetes. J Diabetes Complications. 2015; 29(8):1119-23.

2. DEO R., DE LEMOS JA. B-type natriuretic peptide in ischemic heart disease. Curr Cardiol Rep. 2003; 5(4):271-7.

3. LUCHNER A., STEVENS TL., BORGESON DD., REDFIELD M., WEI CM., PORTER JG., et al. Differential atrial and ventricular expression of myocardial BNP during evolution of heart failure. Am J Physiol. 1998; 274(5 Pt 2):H1684-9.

4. POPELOVA JR., KOTASKA K., TOMKOVA M., TOMEK J. Usefulness of N-terminal-pro-Brain Natriuretic Peptide to predict mortality in adults with congenital heart disease. Am J Cardiol. 2015; 116(9):1425-30.

5. HEDBERG P., SELMERYD J., LEPPERT J., HENRIKSEN E. Left atrial minimum volume is more strongly associated with $N$ terminal pro-B-type natriuretic peptide than the left atrial maximum volume in a community-based sample. Int $\mathrm{J}$ Cardiovasc Imaging. 2016; 32(3):417-25.

6. SIVA SANKARA C., RAJASEKHAR D., VANAJAKSHAMMA V., PRAVEEN KUMAR BS., VAMSIDHAR A. Prognostic significance of NT-probnp, 3D LA volume and LV dyssynchrony in patients with acute STEMI undergoing primary percutaneous intervention. Indian Heart J. 2015; 67(4):318-27.

7. EINDHOVEN JA., VAN DEN BOSCH AE., RUYS TP., OPIC P., CUYPERS JA., MCGHIE JS., et al. N-terminal pro-B-type natriuretic peptide and its relationship with cardiac function in adults with congenital heart disease. $\mathrm{J}$ Am Coll Cardiol. 2013; 62(13):1203-12.

8. BISSESSOR N., WEE YS., JAYASINGHE R., ZENG I., LOWE B., KOLBE J., et al. Complimentary roles for N-terminal proB-type natriuretic peptide and spirometry to assess functional capacity in patients with complex mixed heart valve disease. Kardiol Pol. 2010; 68(1):1-10.

9. POURAFKARI L., SEYEDHOSSEINI S., KAZEMI B., ESMAILI H., ASLANABADI N. Changes in serum NT-pro-BNP and left atrial BNP levels after percutaneous transvenous mitral commissurotomy in sinus rhythm versus atrial fibrillation. J Cardiovasc Thorac Res. 2014; 6(3):175-9.

10. RAMAKRISHNAN S., AGARWAL A., SINGH S., KARTHIKEYAN G., SETH S., NARANG R., et al. NT-pro-BNP levels as a marker of success of percutaneous transvenous mitral commissurotomy. Indian Heart J. 2010; 62(1):35-8.

11. ARAT-OZKAN A., KAYA A., YIGIT Z., BALCI H., OKCUN B., YAZICIOGLU N., et al. Serum N-terminal pro-BNP levels correlate with symptoms and echocardiographic findings in patients with mitral stenosis. Echocardiography. 2005; 22(6):473-8.

12. ERYOL NK., DOGAN A., OZDOGRU I., INANC MT., KAYA MG., KALAY N. The relationship between the level of plasma B-type natriuretic peptide and mitral stenosis. Int J Cardiovasc Imaging. 2007; 23(5):569-74.

13. ILTUMUR K., KARABULUT A., YOKUS B., YAVUZKIR M., TASKESEN T., TOPRAK N. N-terminal pro-BNP plasma levels correlate with severity of mitral stenosis. J Heart Valve Dis. 2005; 14(6):735-41.

14. UCAR O., BAYAR N., KARAGOZ A., AYDOGDU S. Valvular heart disease: plasma B-type natriuretic peptide levels in patients with pure rheumatic mitral stenosis. Acta Cardiol. 2012; 67(1):59-64.

15. ESMAEILZADEH M., NIKPARVAR M., MALEKI M., NOOHI F., OJAGHI HAGHIGHI Z., SAMIEI N., et al. Assessment of inter and intra-atrial asynchrony in patients with systolic heart failure using velocity vector imaging. Res Cardiovasc Med. 2013; 2(3):114-20.

16. BUOB A., JUNG J., SIAPLAOURAS S., NEUBERGER HR., MEWIS C. Discordant regulation of CRP and NT-probnp plasma levels after electrical cardioversion of persistent atrial fibrillation. Pacing Clin Electrophysiol. 2006; 29(6):559-63.

17. DANICEK V., THEODOROVICH N., BAR-CHAIM S., MILLER A., VERED Z., KOREN-MORAG N., et al. Sinus rhythm restoration after atrial fibrillation: the clinical value of $N$-terminal pro-BNP measurements. Pacing Clin Electrophysiol. 2008; 31(8):955-60.

18. MOLLMANN H., WEBER M., ELSASSER A., NEF H., DILL T., RIXE J., et al. NT-pro-BNP predicts rhythm stability after cardioversion of lone atrial fibrillation. Circ J. 2008; 72(6):921-5.

19. SHIN DI., JAEKEL K., SCHLEY P., SAUSE A., MULLER M., FUETH R., et al. Plasma levels of NT-pro-BNP in patients with atrial fibrillation before and after electrical cardioversion. Z Kardiol. 2005; 94(12):795-800.

20. TSUCHIDA K., TANABE K. Influence of paroxysmal atrial fibrillation attack on brain natriuretic peptide secretion. J Cardiol. 2004; 44(1):1-11.

21. RANGANAYAKULU KP., RAJASEKHAR D., VANAJAKSHAMMA V., SANTOSH KUMAR C., VASUDEVA CHETTY P. $N$-terminal-pro-brain natriuretic peptide, a surrogate biomarker of combined clinical and hemodynamic outcomes following percutaneous transvenous mitral commissurotomy. J Saudi Heart Assoc. 2016; 28(2):81-8.

22. CHADHA DS., KARTHIKEYAN G., GOEL K., MALANI SK., SETH S., SINGH S., et al. N-terminal pro-BNP plasma levels before and after percutaneous transvenous mitral commissurotomy for mitral stenosis. Int J Cardiol. 2010; 144(2):238-40.

Received October 23, 2016 